\title{
The synergetlc effect of redox mediators and peroxidase in a bienzymatic biosensor for glucose assays in FIA
}

\author{
A. Rondeau ${ }^{1}$, N. Larsson ${ }^{2}$, M. Boujtita ${ }^{1}$, L. Gorton ${ }^{2}$ and N. El Murr ${ }^{1, *}$ \\ ${ }^{1}$ Groupe Électrochimie, Laboratoire d'Analyse Isotopique et Électrochimique de Métabolismes, \\ (UPRESA-CNRS: 6006), Faculté des Sciences et des Techniques, 2, rue de la Houssinière, B.P. 92208, \\ 44322 Nantes Cedex 03, France \\ ${ }^{2}$ Department of Analytical Chemistry, Lund University, P.O. Box 124, S-221 00 Lund, Sweden
}

\begin{abstract}
A bienzymatic biosensor incorporating a mediator has been developed in order to achieve a fast and selective detection of glucose in a flow injection system. The working electrode is based on a carbon paste matrix bulk modified with glucose oxidase (GOD) and horseradish peroxidase (HRP) as well as with ferrocene acting as an electron transfer mediator between the electrode and HRP. The proximity of these three components enhances the electron transfer within the electrode. Simple polishing on a paper sheet easily renews the electrode surface. Moreover, the applied working potential $(-0.050 \mathrm{~V} v s$. $\mathrm{Ag} / \mathrm{AgCl})$ is 1 low, hereby decreasing the interference from electroactive compounds and thus increasing the selectivity of the biosensor. The characteristics of the developed bienzymatic electrode are presented in terms of sensitivity, linear detection range, accuracy and operational stability.
\end{abstract}

Keywords. biosensor - glucose oxidase - peroxidase - ferrocene - carbon paste.

\section{Introduction}

Amperometric biosensors based on enzymes are interesting due to their high sensitivity, excellent selectivity, simplicity, low cost and rapid response. The most frequently used enzymatic methods for glucose determination employ glucose oxidase (GOD), due to its high selectivity towards $\beta$-D-glucose. In the presence of GOD, the oxidation of glucose occurs, producing $\mathrm{H}_{2} \mathrm{O}_{2}$. Most commonly, the electrochemical detection is performed through the anodic oxidation of $\mathrm{H}_{2} \mathrm{O}_{2}$ [1]. A drawback with this detection technique is that high overvoltages are required, and an applied potential in the range of $0.6-1.1 \mathrm{~V} v s . \mathrm{Ag} / \mathrm{AgCl}$ is necessary. Working at such high potentials increases the risk of interference from easily oxidisable compounds such as ascorbate, ureate, acetaminophen, paracetamol, phenols, etc. which are common compounds in biological samples.

A possible way of improving the selectivity of such a biosensor is to couple a second enzyme (peroxidase) to the oxidase, creating a bienzymatic sensor. Peroxidase catalyses the electrochemical reduction of $\mathrm{H}_{2} \mathrm{O}_{2}$ produced by GOD through a direct electron transfer reaction at a much lower applied potential compared with electrochemical oxidation of $\mathrm{H}_{2} \mathrm{O}_{2}$ and maximum catalytic current can be obtained at carbon electrodes in a potential range of -0.1 and $0 \mathrm{~V}$ [2-14]. However, the kinetics of the direct electron transfer from an electrode to the peroxidase is a sluggish process [15-17] hence the advantage of using a mediator.
The introduction of a mediator in the bienzymatic system (GOD/HRP) leads to an acceleration of the electron transfer, a decrease in the applied working potential (the reduction of the mediator is detected at the electrode) and an increase in sensitivity. The use of mediators is a well-known technique although the way of adding the mediator to the bienzymatic system (oxidase/peroxidase) may vary. A number of different mediators have been used as additions into sample solutions such as, potassium hexacyanoferrate (II) [18-24], hydroquinone [25], o-phenylenediamine [26] and monocarboxylferrocene [27-29] etc. Bienzymatic biosensors have also been developed with deposition of mediators such as hydroxymethyl ferrocene [30], 1,1'-dimethyl ferrocene [31], tetracyanoquinodimethane (TCNQ) [32], and 3,3',5,5'tetramethylbenzidine [33] on the surface or inside the electrode. Moreover, different redox polymers have been used as mediators including osmium polymers [34-41], polypyrrole [42, 43], ferrocene polymers [44, 45], and Nafion-Nmethyl phenazinium [46]. The advantages of using the redox polymers are several, but mainly they result in more stable biosensors since leaking of the mediator from the electrode is minimised and higher and faster responses are observed due to the proximity between the enzyme and the mediator. Although, choosing an appropriate bulk matrix and mediator concentration these properties can be achieved with nonpolymeric mediators and recently a ferrocene mediated bienzymatic graphite-Teflon electrode has been developed for batch and flow-injection measurements [47]. On the other hand several biosensors based on monoenzymatic electrodes 
(HRP) coupled with ferrocene have been reported [48-53]. In this paper we present a bienzymatic (GOD/HRP) carbon paste based biosensor mediated by ferrocene and describe its analytical behaviours.

The use of carbon paste as electrode material offers several advantages over conventional solid material based sensors [53], (1) it is a convenient matrix for the incorporation of biological components, (2) it allows an intimate contact between enzymes, mediator and sensing sites permitting a fast electron transfer, (3) it is versatile, stable and the surface is easily renewed with good reproducibility. Most of the previous publications on bienzymatic biosensors coupled with a mediator for glucose determination in flow injection mode, are based on glassy carbon electrodes with the enzymes immobilised near a redox polymer [34-37, 39, 42$45]$, or on carbon paste with HRP covered by a membrane, coupled with a GOD reactor [32].

\section{Experimental}

\section{Materials}

The enzymes, glucose oxidase (GOD, EC 1.1.3.4) (Cat. No. $1387227,138.46 \mathrm{U} / \mathrm{mg}$, activity not $\mathrm{O}_{2}$ saturated) and horseradish peroxidase (HRP, EC 1.11.1.7) (Cat. No. 815 462, $934 \mathrm{U} / \mathrm{mg}$ ) were purchased from Boehringer Mannheim, Mannheim, Germany. The mediator bis(cyclopentadienyl) iron (ferrocene, FcH, Cat. No. 46260) and the anhydrous D(+)-Glucose (Cat. No. 49140) were obtained from Fluka, Buchs, Switzerland. Potassium dihydrogen phosphate $\left(\mathrm{KH}_{2} \mathrm{PO}_{4}\right.$, Cat. No. 141509) and di-potassium hydrogen phosphate $\left(\mathrm{K}_{2} \mathrm{HPO}_{4}\right.$, Cat. No. 141512) were obtained from Panreac, Barcelona, Spain. Graphite powders were from, Carbone Lorraine (Cat. No. 16855), Gennevilliers, France, and Fluka (Cat. No. 50870). Glassy carbon powder, Sigradur-G (particle size 0.4-12 $\mu \mathrm{m}$ ) was purchased from Hochtemperatur-Werkstoffe $\mathrm{GmbH}$, Thierhaupten, Germany. Paraffin oil was from Merck, Darmstadt, Germany and sodium m-periodate $\left(\mathrm{NaIO}_{4}\right)(\mathrm{Cat}$. No. S-1147) was obtained from Sigma, St. Louis, MO, USA. All aqueous solutions were prepared with distilled water.

\section{Equipment}

All the measurements were done in a flow injection system (FI). The carbon paste electrode (CPE) was packed in a plastic tube $(3 \mathrm{~mm}$ id), provided with a platinum contact. This working electrode was mounted in a three electrodes flow through cell of the wall-jet type. The cell contained an $\mathrm{Ag} / \mathrm{AgCl}(0.1 \mathrm{M} \mathrm{KCl})$ reference electrode and a $\mathrm{Pt}$ wire served as a counter electrode. The electrodes were connected to a potentiostat (milliamperemetre Universal type MAR-U, Tacussel Electronic, Villeurbanne, France) and a recorder was used to register the electrode response (Linseis, L4100, Selb, Germany). The wall-jet cell was incorporated into a FIA set-up consisting of a 4-channel peristaltic pump (Ismatec-Reglo MS-4/8-100 ISM 827, Glattbrugg-Zürich,
Switzerland). The samples $(100 \mu \mathrm{l})$ were injected through a Rheodyne 7010 injection valve, connected to a solenoid valve kit (Rheodyne Model 7163, Bioblock Scientific, Illkirch, France) with a pneumatic actuator. The connections between the different parts of the FI system were made with Tygon tubing (R 3607-1.52 mm i.d., Bioblock Scientific). A $0.1 \mathrm{M}$ phosphate buffer $\mathrm{pH} 7.2$ served as the carrier solution and was pumped at $0.8 \mathrm{ml} / \mathrm{min}$.

\section{The basic preparation procedure for the modified carbon paste}

The first step in the paste preparation procedure was to chemically treat dissolved HRP in aqueous solution with $\mathrm{NaIO}_{4}$, whereby the sugar residues of the glycosylated HRP are oxidised to form aldehyde functionalities [55]. These can be further reacted with the amine functions of GOD forming Schiff bases hereby linking the two enzymes together increasing the trapping efficiency of the produced $\mathrm{H}_{2} \mathrm{O}_{2}$ by GOD [56-59]. The quantities given below are for paste preparations based on $400 \mathrm{mg}$ of graphite powder as starting point. $8.56 \mathrm{mg}$ of $\operatorname{HRP}(8000 \mathrm{U})$ were dissolved in $2.5 \mathrm{ml}$ of aqueous solution containing $1.6 \mathrm{mg} / \mathrm{ml}$ of $\mathrm{NaIO}_{4}$ and mixed for $20 \mathrm{~min}$. The solution was then centrifuged $\left(6000 \mathrm{rpm}, 45 \mathrm{~min}, 20^{\circ} \mathrm{C}\right.$ ) through a Centricon concentrator (Amicon, Beverly, MA, USA) with a 30000 Da molecular weight cut-off in order to remove unreacted $\mathrm{NaIO}_{4}$ from the HRP-solution. This step was repeated after adding $1 \mathrm{ml}$ of distilled water in the concentrator. After centrifugation, the HRP was dissolved in $800 \mu$ l of $0.05 \mathrm{M}$ phosphate buffer, $\mathrm{pH}$ 8.0. The resulting HRP solution was added to $400 \mathrm{mg}$ of graphite powder followed by $30 \mathrm{~min}$ of mixing. $800 \mu \mathrm{l}$ of GOD-solution (16 mg, $2215.4 \mathrm{U}$, in $0.05 \mathrm{M}$ phosphate buffer, $\mathrm{pH}$ 8.0) were then added and allowed to thoroughly mix for $60 \mathrm{~min}$. The drying of the bienzymatic powder was done under water jet vacuum in a desiccator for $4-5.5 \mathrm{~h}$, or in a freeze drier (Bioblock Scientific, Type Alpha 1-4, Illkirch, France) for 2 days. The dry mixture was passed through a sieve (pore size: $80 \mu \mathrm{m}$ ) in order to get a homogeneous powder. Finally, the paste was prepared by mixing the enzyme modified powder with either pure paraffin oil to yield a paste containing $24.24 \% \mathrm{w} / \mathrm{w}$ of paraffin oil modified with $\mathrm{FcH}$. The mixing was done by hand for $10 \mathrm{~min}$ in an agate mortar.

\section{Results and discussion}

\section{The effect of the mediator in the bienzymatic (GOD/HRP) paste}

The reaction sequence occurring at the electrode surface yielding a response current for glucose is given in figure 1 . After glucose is oxidised by GOD, the reduced cofactor $\left(\mathrm{FADH}_{2}\right)$ is oxidised by molecular oxygen, transferring the cofactor back into its oxidised state (FAD) with the simultaneous production of $\mathrm{H}_{2} \mathrm{O}_{2}$, which in turn, will be reduced to water by HRP. The oxidised form of HRP can then be rereduced either via direct electron donation from the 


\section{Original articles}

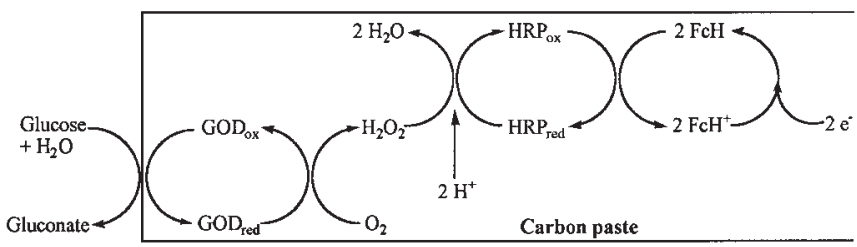

Fig. 1. The reaction sequence of the bienzymatic electrode coupled with ferrocene as the mediator. Operating potential: $-0.050 \mathrm{~V} v s$. $\mathrm{Ag} / \mathrm{AgCl}$.

electrode or through a mediator $(\mathrm{FcH})$. The mediator has an electrochemically reversible reaction and the produced ferricinium cation $\left(\mathrm{FcH}^{+}\right)$can easily be reduced by the electrode (Fig. 1). The recorded current will then be proportional to the glucose concentration in the sample. Previously it has been clearly shown that using polymeric bound mediators and especially polymeric mediators covalently bound with the enzyme is beneficial to obtain stable biosensors [41-60]. However, in the case stipulated in this work when coimmobilising GOD and HRP it has been possible to achieve long term stable sensors. By excluding the time consuming covalent binding of the enzyme with the mediator, the preparation of the paste is easier, cheaper and the risk for loss of sensitivity due to covalent linkages is minimised.

When comparing the results between a mediated $(\mathrm{FcH}$ $0,08 \% \mathrm{w} / \mathrm{w}$ ) and an unmediated paste, the mediated paste resulted in a two-fold increase in response (Fig. 2), proving that the electron transfer between HRP, the mediator and the electrode is more efficient than the direct reduction of the peroxidase by the electrode. The concentration of $\mathrm{FcH}$ was arbitrary chosen. Since glucose oxidase can be directly mediated by ferrocene, the two-enzyme based system might be short-circuited, that is, mediated HRP yields reduction currents and mediated GOD yields oxidation currents (Fig. 1). In [41] Kenausis et al. presented a mediated bienzymatic glassy carbon sensor where they solved the problem with short-circuiting by introducing a cellulose acetate membrane between the two enzyme layers in a multilayer approach. The positive effect of the membrane was proven by poising the electrode at $+0.5 \mathrm{~V}$ (SCE) whereby no oxidation currents were registered. Since an insulating layer is impossible in our bulk modified approach, it became even more important to choose the applied potential so that the reaction is driven towards our preferred direction. The optimum working potential for the electrode was established by injecting successive samples of $100 \mu \mathrm{l}$ of glucose $(200 \mathrm{mg} / \mathrm{l})$ into the FIsystem, and step-wise varying the potential between 0.25 and $-0.25 \mathrm{~V}$ vs. $\mathrm{Ag} / \mathrm{AgCl}$. The resulting hydrodynamic voltammogram is shown in figure 3 . The peak-current versus potential profile reaches a plateau allowing us to work at low negative potentials, but it also indicates short-circuiting of the system since oxidation currents are registered at positive potentials. However, as indicated in figure 2 the gain in sensitivity when the mediator is added still remains substantial. A working potential of $-0.050 \mathrm{~V}$ was selected for

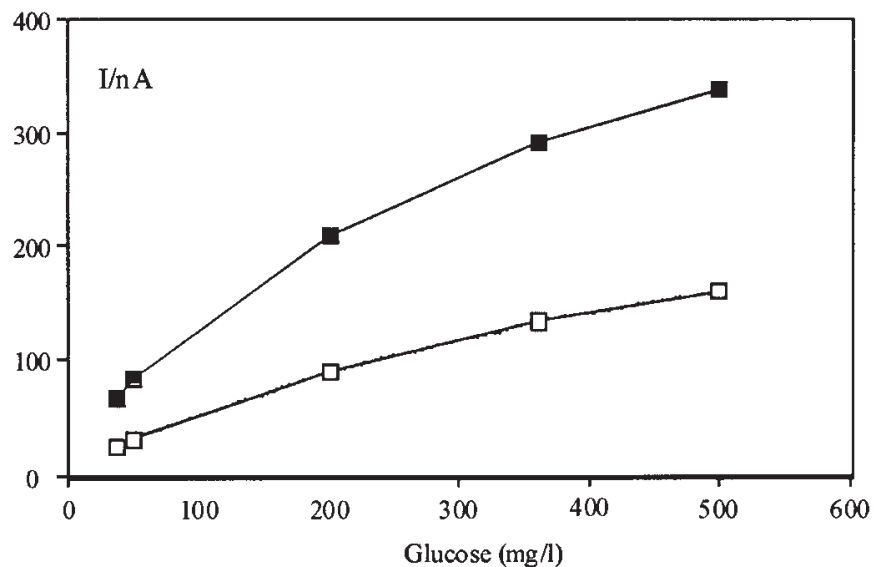

Fig. 2. Comparison between two bienzymatic pastes (n) (GOD/HRP; 1108U / 4016U for $400 \mathrm{mg}$ of Lorraine graphite powder) with $(0.08 \%)$ or $(\circ)$ without $\mathrm{FcH} . \mathrm{E}_{\mathrm{appl}}=-0.050 \mathrm{~V}$ vs. $\mathrm{Ag} / \mathrm{AgCl}$, carrier solution: $0.1 \mathrm{M}$ phosphate buffer, $\mathrm{pH} 7.20$, flow rate $0.80 \mathrm{ml} / \mathrm{min}$ and $100 \mu \mathrm{l}$ injection volume.

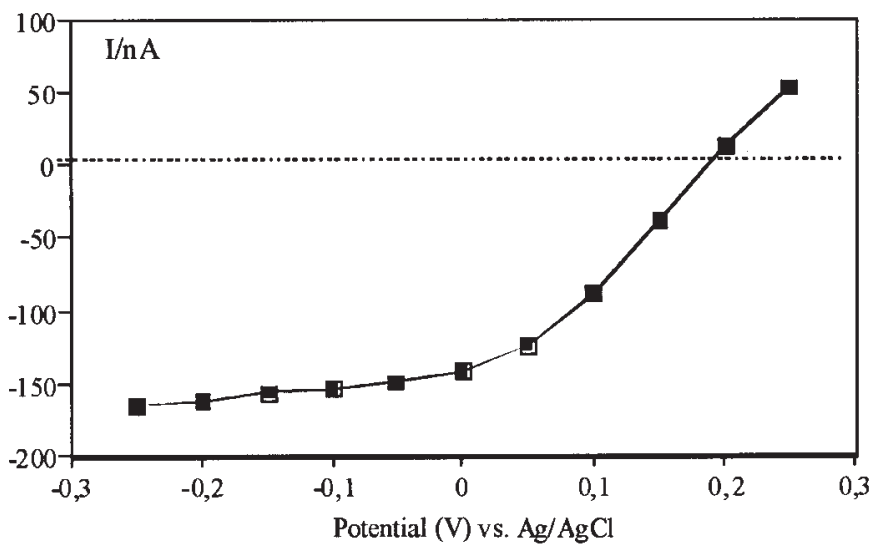

Fig. 3. Hydrodynamic voltammogram from the GOD/HRP/FcH (0.08\%)-based paste. Sample solution (glucose, $200 \mathrm{mg} / \mathrm{l}$ ), experimental conditions as in figure 2 .

further measurements, taking into account that the peak intensity has reached the plateau and that the potential is not negative enough to allow direct electrochemical reduction of $\mathrm{H}_{2} \mathrm{O}_{2}$, molecular oxygen or interference from other compounds present in a complex sample. A potential of $-0.050 \mathrm{~V}$ will also very rapidly rereduce $\mathrm{FcH}^{+}$back into $\mathrm{FcH}$, thereby minimising the risk that $\mathrm{FcH}^{+}$should compete with molecular oxygen as electron acceptor for reduced GOD.

\section{Optimisation of the paste composition}

The influence of the amount and ratio of both enzymes on the biosensor performances

Four pastes (GOD/HRP/FcH $(0.08 \%)$ ) were prepared by varying the amounts of the enzymes. Calibration curves 
between 40 and $500 \mathrm{mg} / \mathrm{l}$ of glucose were examined for the different pastes as a way of comparing the performance of the electrodes (Fig. 4). The results clearly showed that the carbon paste with a higher amount of GOD and HRP resulted in higher sensitivity. Moreover, the effect was more profound when only the GOD amount was increased (paste 1 compared with paste 3 and paste 2 with paste 4) indicating that GOD is the rate limiting enzyme in the electron transfer chain. Higher amounts of enzymes were not desirable since the amount of electrically insulating proteins would be too high, resulting in high background currents and poor electrode stability. For further work, the enzyme composition of paste 1 (HRP/GOD: 3.6/1) was used.

\section{The influence of the carbon powder on the biosensor performances}

Graphite powder contains a vast number of different chemical functions (quinone-, hydroxy-, ketone- and carboxygroups), that have a large effect on enzyme immobilisation and the electron transfers [61]. Three types of carbon and glassy carbon powder (C. Fluka, C. Lorraine. and C. Sigradur G) were studied. Regarding the background current, the glassy carbon powder gave higher intensity $(-40 \mathrm{nA})$ compared with the graphite carbon powder (Lorraine: $-15 \mathrm{nA}$, Fluka: $+15 \mathrm{nA}$ ). The noise was the same for the graphite carbon powder Fluka and the glassy carbon powder Sigradur G (4 nA), whereas it was four times less for the graphite carbon powder from Carbone Lorraine. The carbon powder Fluka (graphite) increased the current response (sensitivity more than 2.5 times higher than with the other two powders) (Fig. 5). It is well known that the glassy carbon material yields lower noise and background current due to its more organised structure when it comes to solid material electrodes but in our case the opposite seems to be the case. The reason for this is not fully understood although a possible explanation is that the glassy carbon is less porous and does not absorb as much oil as the graphite powders, resulting in a thin film of oil on the electrode surface, and therefore in poor performances. No further investigation was done on this phenomenon since the Fluka powder gave both high response and low background current making it the obvious choice for our further studies. The results are in agreement with the work of Popescu et al. [12] who in 1995 selected the carbon powder Fluka for its performance with HRP. The HRP adsorption on the carbon powder occurred via electrostatic interactions, especially on the hydrophilic part of the carbon, rich of carbonyl functions. For an efficient adsorption of the enzymes, the surface of the graphite particles must be relatively high. The graphite powder Fluka, with a surface area of $13.5 \mathrm{~m}^{2} / \mathrm{g}$, answers to this requirement.

\section{The effects of the amount of oil and mediator in the paste}

Four different pastes were prepared by varying the amount of oil (24.2 and $27.0 \%)$ and mediator $(0.08$ and $0.16 \%)$. The combination yielding the best sensitivity was the paste containing $0.16 \%$ mediator and $24.2 \%$ oil (Fig. 6). Due to the

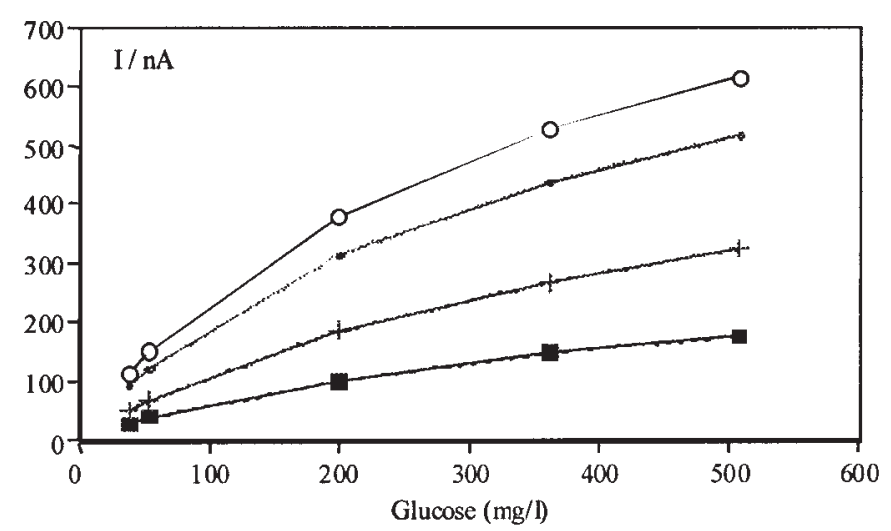

Fig. 4. Comparison between 4 pastes (GOD/HRP/FcH $(0.08 \%)$ ) with different amounts of enzymes, (O) Paste 1: GOD 4U/mg, HRP 14.5U/mg, (.) Paste 2: GOD 4U/mg, HRP 7.4U/mg, (+) Paste 3: GOD 2U/mg, HRP 14.5U/mg, and $(\Delta)$ Paste 4: GOD 2U/mg, HRP 7.4U/mg. Experimental conditions as in figure 2.

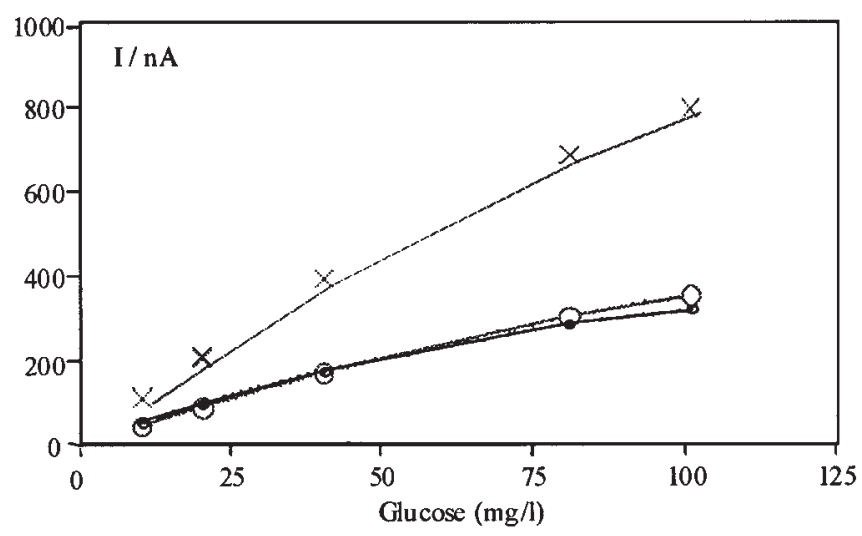

Fig. 5. Effect of the different graphite and glassy carbons, (X) Fluka, (O) Sigradur G and (.) Carbone Lorraine on the calibration curve $(10-100 \mathrm{mg} / \mathrm{l})$ for the pastes (GOD/HRP/FcH $(0.08 \%)$ ). Experimental conditions as in figure 2.

loss of the mechanic stability of the paste further decrease of the amount of oil was impossible. Further optimisation of the required amount of $\mathrm{FcH}$ was done by preparing three pastes with more mediator ( $\mathrm{P} 10.16 \%, \mathrm{P} 20.24 \%$ and $\mathrm{P} 3$ $0.32 \%)$. The pastes were characterised by investigating the accuracy (calculated error $(\% e C)$ on the determined concentration) (Fig. 7) and the precision on 20 successive injections of the same glucose concentration (Fig. 8). \%eC is calculated as:

$$
\% e C=\frac{C_{\text {cal }}-C_{\text {real }}}{C_{\text {real }}} * 100
$$




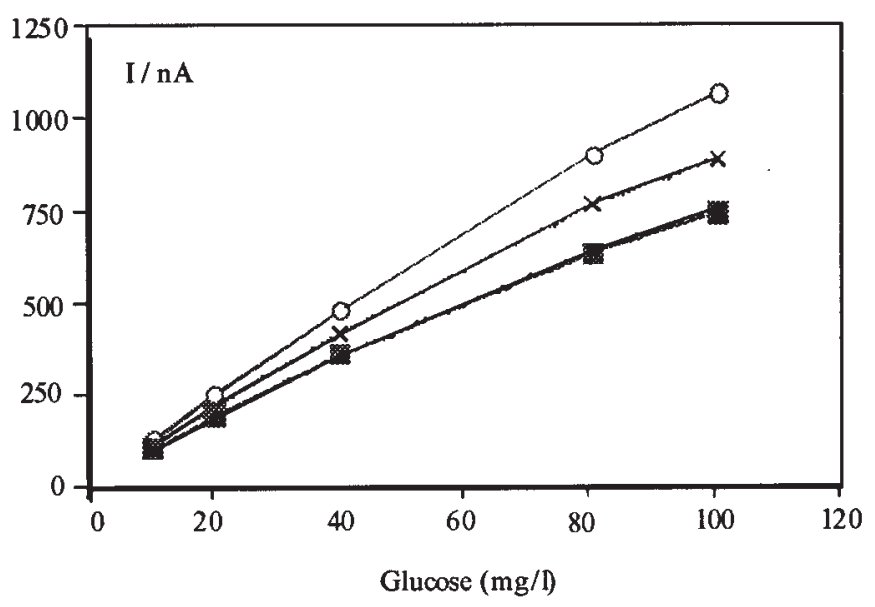

Fig. 6. The effects of varying the amount of oil and mediator in the bienzymatic paste: (O) Paste A: $24.2 \%$ Parafin oil, $0.16 \% \mathrm{FcH}$, (x) Paste B: $27.0 \%$ Parafin oil, $0.16 \% \mathrm{FcH}$, (.) Paste C: $24.2 \%$ Parafin oil, $0.08 \% \mathrm{FcH}$ and ( $\square$ ) Paste D: $27.0 \%$ Parafin oil, $0.08 \%$ $\mathrm{FcH}$. Experimental conditions as in figure 2.

where: $\mathrm{C}_{\mathrm{cal}}$ is the calculated glucose concentration $\left(C_{c a l}=\frac{I_{m e s}-b}{a}\right), \mathrm{I}_{\text {mes }}$ the measured current, $\mathrm{C}_{\mathrm{real}}$ the real glucose concentration, and where $\mathrm{a}$ and $\mathrm{b}$ are the slope and intercept of the calibration curve, respectively.

When the amount of the mediator was increased $(0.32 \%)$, a linear range between 5 and $50 \mathrm{mg} / \mathrm{l}$ of glucose was obtained with good accuracy $(\% \mathrm{eC} \leq 3 \%$ for each concentration except for $5 \mathrm{mg} / \mathrm{l}$, where $\% \mathrm{eC} \leq 5 \%$ ). Moreover, the accuracy for 20 successive injections of glucose $(25 \mathrm{mg} / \mathrm{l})$ after the calibration, was acceptable (\%eC $\leq 3 \%$ ) (Fig. 8). High amounts of mediator usually result in leakage from the paste resulting in a fast decrease in response with time when the electrode is continuously used in a FI-system and considering this, no further increase in mediator content was done. The paste with the high amount of mediator $(0.32 \%)$ was now considered optimised and used for all further work reported below.

\section{The effect of $\mathrm{pH}$ on the biosensor performance}

The reaction rate of an enzymatic reaction is always dependent on the $\mathrm{pH}$ of the surrounding environment, and it is desirable to find the optimal $\mathrm{pH}$-value for the enzymatic reaction. Also the pH-optimum for an enzyme in solution and in the matrix of a carbon paste electrode may vary with several $\mathrm{pH}$ units. Considering that the described biosensor contains two enzymes with different $\mathrm{pH}$ optima, the response of the bi-enzyme electrode was investigated between $\mathrm{pH}$ 4.7-10.0. Since enzymes consist of amino acids with an amphoteric nature, which participate in the binding with the substrate, the rate of formation of the enzyme-substrate complex depends on the protonation of these amino

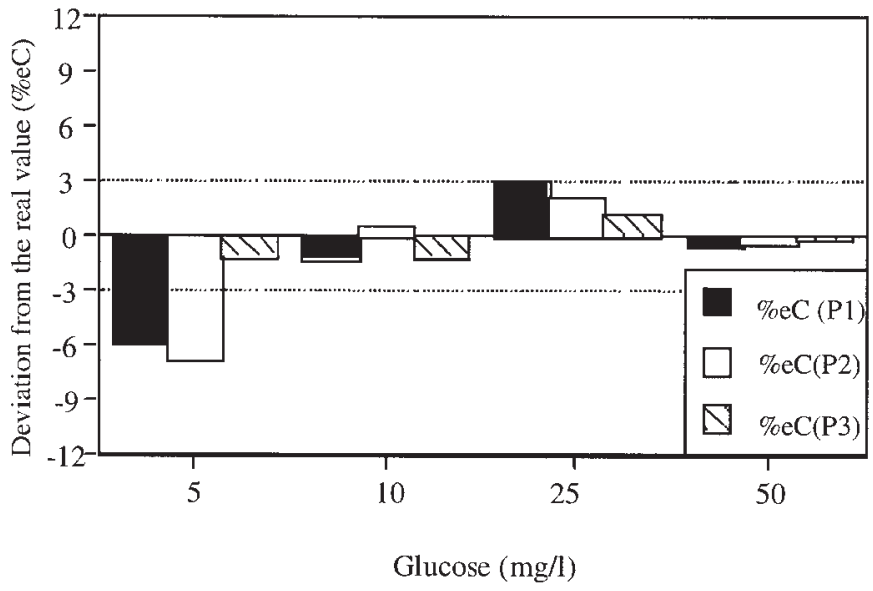

Fig. 7. Accuracy of the calibration curve $(\% \mathrm{eC})$ between 5 and 50 $\mathrm{mg} / \mathrm{l}$ of glucose for the three pastes with different amounts of mediator (P1: $0.16 \%, \mathrm{P} 2: 0.24 \%$ and P3: $0.32 \% \mathrm{FcH})$. Experimental conditions as in figure 2 .

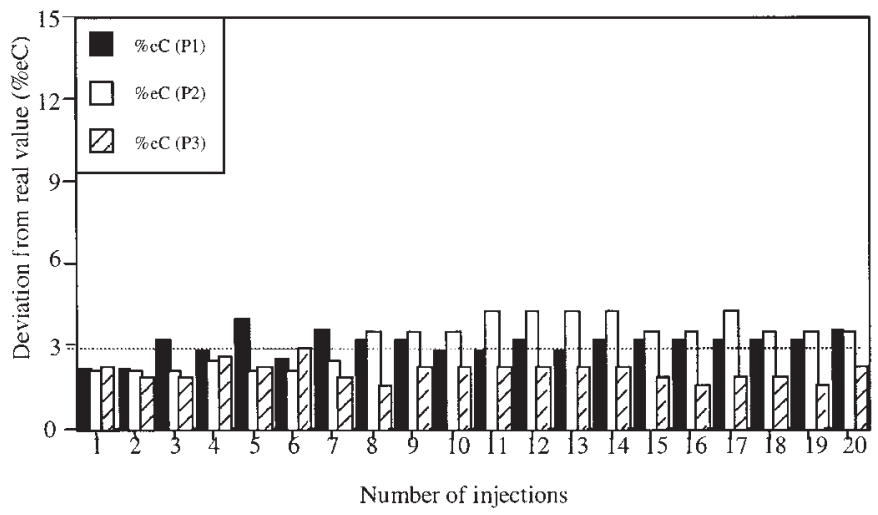

Fig. 8. Accuracy on 20 successive injections of a glucose solution $(25 \mathrm{mg} / \mathrm{l})$ after calibration $(5-50 \mathrm{mg} / \mathrm{l})$; three pastes with different amount of mediator (P1: $0.16 \%, \mathrm{P} 2: 0.24 \%$ and $\mathrm{P} 3: 0.32 \% \mathrm{FcH})$. Experimental conditions as in figure 2.

acids and the optimum $\mathrm{pH}$ is a direct result of these concepts. The best sensitivity with a low value for the intercept and a good accuracy on glucose concentrations was obtained at $\mathrm{pH} 7.2$ (Fig. 9). At basic pH, the sensitivity decreases as well as the accuracy. The decrease in sensitivity at alkaline $\mathrm{pH}$ can be due to the deprotonation of the active centres of the enzymes [62]. Therefore, $\mathrm{pH} 7.2$ was used throughout all further studies. The response towards hydrogen peroxide was not investigated in this study since the goal was to develop a glucose sensor with as high sensitivity as possible but according to previous work the optimum $\mathrm{pH}$ for HRP in carbon paste is around 7-8 [26-48]. 


\section{Original articles}

Table I. Analytical parameters of the calibration curve for the same surface of the working electrode (glucose concentrations being increased and then decreased).

\begin{tabular}{lccc}
\hline & Sensitivity $(n A / l \times m g)$ & Intercept $(n A)$ & $r^{2}$ \\
\hline C1 - C4 & 11.51 & -7.67 & 1.0000 \\
C4 - C1 & 11.40 & -2.37 & 0.9999 \\
\hline
\end{tabular}

\section{Performance of the optimised biosensor}

One disadvantage with the enzyme based biosensors is that if the concentration of substrate to be measured is high, the enzyme might be saturated, and sometimes even permanently inhibited. It is therefore important to investigate the response at low concentrations after high concentrations exposure. We simply used our calibration series and went from low to high to low glucose standards. There is no significant memory effect on the linearity when calibrations were performed in this way (Table I) which indicates that sample measurements within the linear range do not result in substrate induced inhibition. The accuracy is slightly worse in the high-low calibration but still acceptable (that is, within 5\% for the lowest concentration, Fig. 10). The linear range of the biosensor covers a ten-fold range in concentration with very high $\mathrm{r}^{2}$ values $(\geq 0.999)$.

If a biosensor is to be used as an analytical tool in a FIsystem the operational stability has to be high. We investigated the response of 50 successive injections $(25 \mathrm{mg} / \mathrm{l}$ of glucose) and found that our sensor indeed is very repeatable, showing no decrease in signal at all (Fig. 11). The stability of the electrode surface was confirmed with 30 injections per hour for the highest and lowest concentrations from the calibration curve $(5$ and $50 \mathrm{mg} / \mathrm{l})$, with respective standard deviations as $0.90 \%$ and $3.40 \%$. Since it is very simple to expose a new surface on the electrode, an operation that takes around $10 \mathrm{~min}$ including pre-measure stabilisation, 50 injections with no decrease was considered satisfying.

It is not only important with linear calibration curves, repeatability and operational stability, but also the accuracy of actual measurements. If a sample is run and the value of the resulting current is put into the equation of the calibration curve, the calculated value for the concentration should be accurate. As a requirement for our sensor we decided that the deviation may not exceed $3 \%$ and this goal was achieved as indicated from the accuracy of 25 injections of a glucose solution at $35 \mathrm{mg} / \mathrm{l}$ towards the calibration $5-50 \mathrm{mg} / \mathrm{l}(\% \mathrm{eC}$ $\leq 3 \%$ - figure 12 ).

\section{Conclusions}

An enzymatic glucose-sensing electrode was prepared by incorporating GOD, HRP and ferrocene into a carbon paste. The method is highly sensitive between 5 and $50 \mathrm{mg} / \mathrm{l}$ of glucose, and requires only a small sample per assay. The response is very fast (about $1 \mathrm{~min}$ ) and the working potential applied for the reduction of the mediator low $(-0.050 \mathrm{~V}$

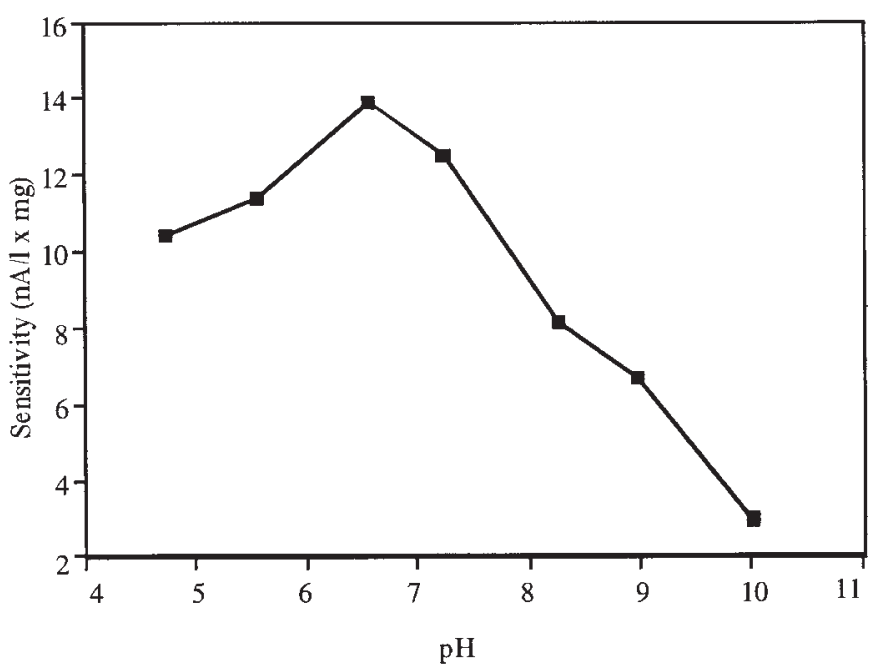

Fig. 9. The effect of the pH-value on the sensitivity for glucose of the GOD/HRP/FcH-based biosensor (glucose concentrations range $5-50 \mathrm{mg} / \mathrm{l}$ ). All other experimental conditions as in figure 2.

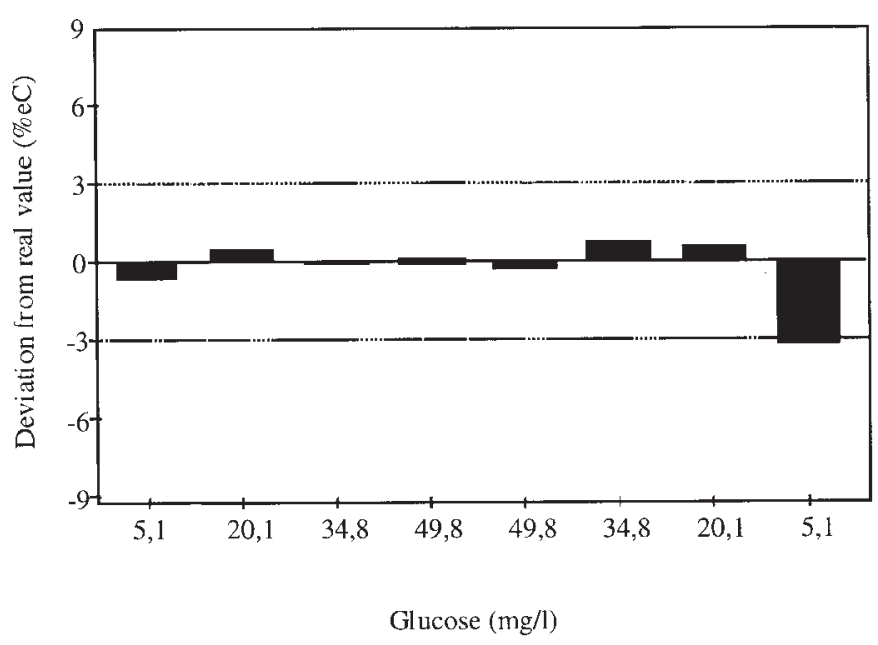

Fig. 10. Accuracy of the calibration curves $(\% e C)$ between 5 and $50 \mathrm{mg} / \mathrm{l}$ of glucose with increasing and decreasing glucose concentrations on the same operating surface. Experimental conditions as in figure 2.

vs. $\mathrm{Ag} / \mathrm{AgCl}$ ), thus this biosensor presents a high selectivity. The mixed carbon paste configuration permits fast electron transfers between the both enzymes and the mediator. The paste presents good shelf life (no decrease in the sensitivity) after 4 months (the longest time period investigated so far), when stored at $4^{\circ} \mathrm{C}$. 


\section{Original articles}

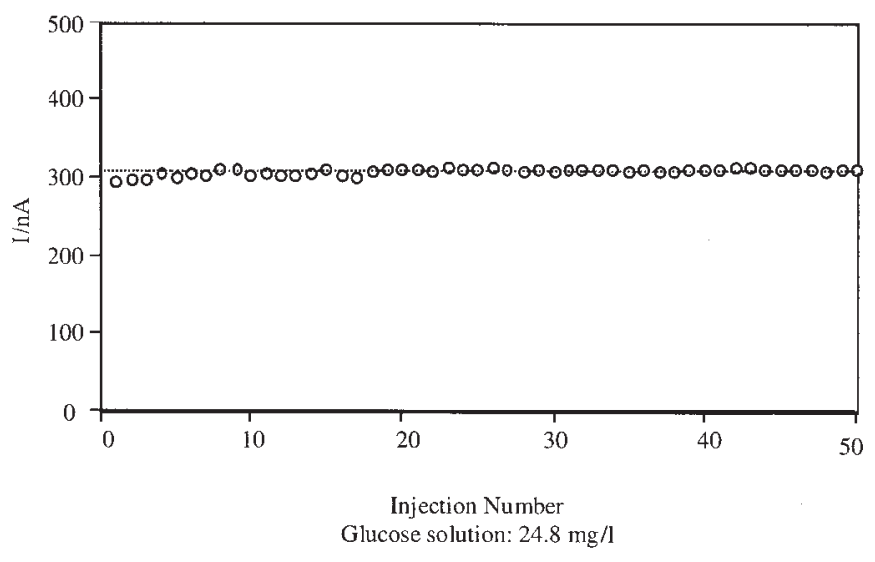

Fig. 11. Operational stability investigated by 50 successive injections (every $2 \mathrm{~min}$ ) of a $24.79 \mathrm{mg} / \mathrm{l}$ glucose solution. Experimental conditions as in figure 2.

\section{Acknowledgement}

Funding from the CNRS and the University of Nantes, the Swedish Board for Technical and Industrial Development (NUTEK) as well as from the European Commission (project $\mathrm{N}^{\circ}$ SMT CT95-2038) is gratefully acknowledged.

\section{References}

1. Guilbault, G. G.; Lubrano, G. J. Anal. Chim. Acta 1973, 64, 439.

2. Gorton, L.; Bremle, G.; Csöregi, E.; Jönsson-Pettersson, G.; Persson, B. Anal. Chim. Acta 1991, 249, 43.

3. Yaropolov, A. I.; Malovik, V.; Varfolomeev, S. V.; Berezin, I. V. Dolk. Akad. Nauk. SSSR 1979, 249, 1399.

4. Iwai, H.; Akihama, S. Chem. Pharm. Bull. 1986, 34, 3471.

5. Bogdanovskaya, V. A.; Tarasevich, M. R.; Hintsche, R.; Scheller, F. Bioelectrochem. Bioenerg. 1988, 19, 581.

6. Jönsson, G.; Gorton, L. Electroanalysis 1989, 1, 465.

7. Jönsson-Pettersson, G. Electroanalysis 1991, 3, 741.

8. Kulys, J.; Schmid, R. D. Bioelectrochem. Bioenerg. 1990, 24, 305.

9. Zhao, J.; Henkens, R. W.; Stonehuerner, J.; O`Daly, J. P.; Crumbliss, A. L. J. Electroanal. Chem. 1992, 327, 109.

10. Gorton, L.; Jönsson-Pettersson, G.; Csöregi, E.; Johansson, K.; Domingez E.; Marko-Varga, G. Analyst 1992, 117, 1235.

11. Csöregi, E.; Gorton, L.; Marko-Varga, G.; Tüdös, A. G.; Kok, W. T. Anal. Chem. 1994, 66, 3604.

12. Popescu, I. C.; Zetterberg, G.; Gorton, L. Biosensors \& Bioelectronics 1995, 10, 443.

13. Ruzgas, T.; Csöregi, E.; Emnéus, J.; Gorton, L.; Marko-Varga, G. Anal. Chim. Acta 1996, 330, 123.

14. Ghindils, L.; Atanasov, P.; Willkins, E. Electroanalysis 1997, 9, 661 .

15. Frew, J. E.; Harmer, M. A.; Hill, H. A. O.; Libor, S. I. J. Electroanal. Chem. 1986, 201, 1.

16. Ruzgas, T.; Gorton, L.; Emnéus, J.; Marko-Varga, G. J. Electroanal. Chem. 1995, 391, 41.

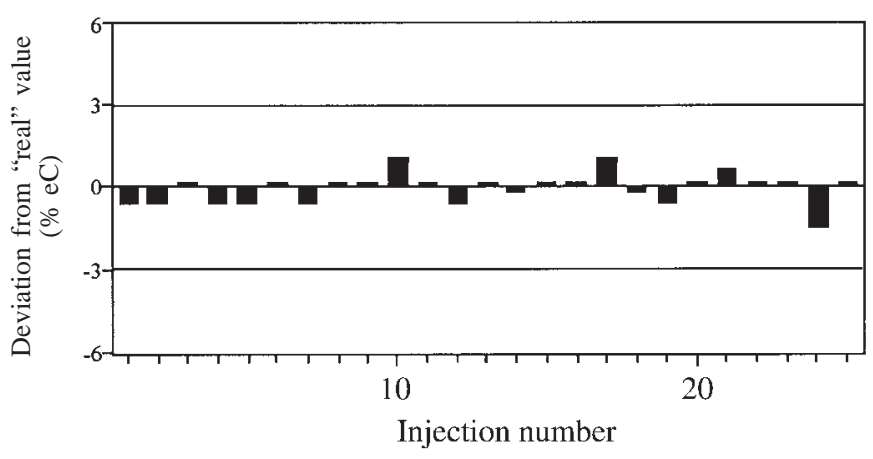

Fig. 12. Accuracy of 25 injections of a glucose solution $(35 \mathrm{mg} / \mathrm{l})$ calculated in comparison with the equation of a calibration curve done on the same surface prior to the 25 injections. Experimental conditions as in figure 2 .

17. Lindgren, A.; Munteanu, F.; Gazaryan, I. G.; Ruzgas, T.; Gorton, L. J. Electroanal. Chem. 1998, 458, 113.

18. Blaedel, V.; Olson, C. L. U. S. Patent 3367 849, 1968.

19. Hahn, Y.; Olson, C. L. Anal. Chem. 1979, 51, 444.

20. Kulys, J. J.; Pesliakiene, M. V.; Samalius, A. S. Bioelectrochem. Bioenerg. 1981, 8, 81.

21. Kulys, J. J.; Laurinavicius, V. S. A.; Pesliakiene, M. V.; Gureviciene, V. V. Anal. Chim. Acta 1983, 148, 13.

22. Yao, T.; Sato, M.; Kobayashi, Y.; Wasa, T. Anal. Chim. Acta 1984, 165, 291.

23. Moody, G. J.; Sanghera, G. S.; Thomas, J. D. R. Analyst 1987, 112,65 .

24. Elekes, O.; Moscone, D.; Venema, K.; Korf, J. Clinica Chimica Acta 1995, 239, 153.

25. Hintsche, R.; Scheller, F. W. Studia biophysica 1987, 119, 179.

26. Wang, J.; Lin, M. S. Electroanalysis 1989, 1, 43.

27. Tatsuma, T.; Okawa, Y.; Watanabe, T. Anal. Chem. 1989, 61, 2352.

28. Tatsuma, T.; Watanabe, T. Anal. Chim. Acta 1991, 242, 85.

29. Boutelle, M. G.; Fellows, L. K.; Cook, C. Anal. Chem. 1992, 64, 1790.

30. Ball, M. R.; Frew, J. F.; Green, M. J.; Hill, H. A. O. Electrochemical Sensors for Biomedical Applications, Ed. C.K.N.Li, The Electrochem. Soc., Proceedings volume 1986, 86-14, 16.

31. Yabuki, S.; Mizutani, F. Biosensors \& Bioelectronics 1995, 10, 353.

32. Pandley, P. C.; Weetall, H. H. Anal. Biochem. 1995, 224, 428.

33. Compagnone, D.; Schweicher, P.; Kauffman, J. M.; Guilbault, G. G. Anal. Letters 1998, 31, 1107.

34. Maidan, R.; Heller, A. Anal. Chem. 1992, 64, 2889.

35. Garguilo, M. G.; Huyn, N.; Proctor, A.; Michael, A. C. Anal. Chem. 1993, 65, 523.

36. Vreeke, M. S.; Rocca, P. Electroanalysis 1996, 8, 55.

37. Heller, A. J. Phys. Chem. 96, 1992, 3579.

38. Vijayakumar, A. R.; Csöregi, E.; Heller, A.; Gorton, L. Anal. Chim. Acta 1996, 327, 223.

39. Larsson, N.; Ruzgas, T.; Gorton, L.; Kokkaia, P.; Kissinger, P.; Csöregi, E. Electrochim. Acta 1998, 43, 3541. 


\section{Original articles}

40. Belay, A.; Collins, A.; Ruzgas, T.; Kissinger, P.; Gorton, L.; Csöregi, E. J. Pharm. Biomed. Anal. 1999, 19, 93.

41. Kenausis, G.; Chen, Q.; Heller, A. Anal. Chem. 1997, 69, 1054.

42. Wollenberger, U.; Bogdanovskaya, V.; Bobrin, S.; Scheller, F.; Tarasevich, M. Anal. Letters 1990, 23, 1795.

43. Popescu, I. C.; Cosnier, S.; Labbe, P. Electroanalysis 1997, 9 , 998.

44. Mulchandani, A.; Wang, C. L. Electroanalysis 1996, 8, 414.

45. Boguslavsky, L.; Kalash, H.; Xu, Z.; Beckles, D.; Geng, L.; Skotheim, J.; Laurinavicius, V.; Lee, H.S. Anal. Chim. Acta 1995, 311, 15.

46. Liu, H. Y.; Ying, T. L.; Sun, K.; Li, H. H.; Qi, D. Y. Anal. Chim. Acta 1997, 344, 187.

47. del Cerro, M. A.; Cayuela, G.; Reviejo, A. J.; Pingarron, J. M.: Wang, J. Electroanalysis 1997, 9, 1113.

48. Sanchez, P. D.; Ordierez, A. J. M.; Garcia, A. C.; Blanco, P. T. Electroanalysis 1991, 3, 281.

49. Chen, L.; Lin, M. S.; Hara, M.; Rechnitz, G. A., Analytical Letters 1991, 24, 1.

50. Wang, J.; Ciszewski, A.; Naser, N. Electroanalysis 1992, 4, 777 .
51. Wang, J.; Reviejo, A. J.; Angnes, L. Electroanalysis 1993, 5, 575.

52. Charpentier, L.; El Murr, N. Analusis 1995, 23, 265.

53. Gorton, L. Electroanalysis 1995, 7, 23.

54. Appelquist, R.; Marko-Varga, M.; Gorton, L.; Torstensson, A.; Johansson, G.; Anal. Chim. Acta 1985, 169, 237.

55. Wilson, M. B.; Nakane, P. K. Immunofluorescence and Related Staining Techniques, Ed. W. Knapp, K. Holubar and G. Wick, Elsevier/North-Holland Biomedical Press, Amsterdam, 1978, 215.

56. Wang, D. L.; Heller, A. Anal. Chem. 1993, 65, 1069.

57. Vreeke, M.; Maidan, R.; Heller, A. Anal. Chem. 1992, 64, 3084.

58. Ohara, T. J.; Vreeke, M. S.; Battaglini, F.; Heller, A Electroanalysis 1993, 5, 825.

59. Tijssen, P.; Kurstak, E. Anal. Biochem. 1984, 136, 451.

60. Chuang, C. L.; Wang, Y. J.; Lan, H. L. Anal. Chim. Acta 1997, 353, 37.

61. McCreery, R. L. Electroanalytical Chemistry, Ed. A. J. Bard and M. Dekker, New York 1991, 17, 221.

62. Kulys, J.; Drungiliene, A.; Wollenberger, U.; Krikstopaitis, K.; Scheller, F. Electroanalysis 1997, 9, 213. 